\title{
STUDY ON RISK IDENTIFICATION AND PESTICIDE USAGE IN PADDY CULTIVATION IN ALAYADIVEMBU DIVISIONAL SECRETARIAT DIVISION OF AMPARA DISTRICT, SRI LANKA
}

\author{
K. Prasannath ${ }^{1 *}$, V. Prasannath ${ }^{2}$ and S. Sinthuja ${ }^{1}$ \\ ${ }^{1}$ Department of Agricultural Biology, Eastern University, Sri Lanka \\ ${ }^{2}$ Department of Biosystems Technology, Eastern University, Sri Lanka
}

Email:* prasannathk@esn.ac.lk

\begin{abstract}
Synthetic pesticide application has been the chief method of pest control in paddy cultivation in Sri Lanka. In this context, the objectives of the study were to assess the kind of risk exposures on paddy cultivation and identification of predominant pests in the Alayadivembu Divisional Secretariat (DS) division of Ampara and evaluate the coping mechanisms used for pest management. Stratified random sampling method was used to select 100 farmers from the Alayadivembu DS division which is a predominantly paddy cultivating area. Pre-tested structured questionnaires were used to collect data during yala 2016 cropping season. Descriptive statistics, correlation analysis and ordered probit regression analysis were used for analyzing data. The results of the study indicate that the foremost cause of risk was weeds (96\%) such as Jungle Rice (72\%) followed by Wrinkle Duck Beak (56\%) and Umbrella Sedge (52\%). The other causes of risks were insects (88\%) namely Brown Plant Hopper (70\%) and Thrips (50\%) while Fungi attacks were insignificant. Percentage of farmers having more than 5 years of experience in paddy cultivation was $80 \%$. The average extent of cultivation was 5.35 acres where only $18 \%$ of respondents' cultivated land size was greater than 10 acres. All the farmers (100\%) applied chemical pesticides where $74 \%$ of farmers used mechanical means as well to manage these risks. Only $32 \%$ of farmers received extension service. Correlation analysis indicates that farmers' income and knowledge on integrated pest management were significantly $(\mathrm{p}<0.05)$ influenced by extent of paddy cultivation and educational level respectively. Results of ordered probit regression analysis reveal that farmers' educational level, farming experience and access to extension service had a positive and significant $(p<0.05)$ relationship on farmers' correct identification of risk in the field.
\end{abstract}

Keywords: Alayadivembu DS Division; Paddy; Pesticide; Pests; Socio-Economic Factors

\section{Introduction}

Sri Lanka is an agricultural country as majority of the rural people is still engaged in agriculture for their main livelihood. Agriculture is a crucial sector in the economy contributing to 7.1\% as a share of the Gross Domestic Product for the year 2016 (Central Bank of Sri Lanka, 2016). In the agricultural sector of Sri Lanka, rice is the foremost important subsector. Ampara, a coastal district in the Eastern Province of Sri Lanka, falls under the dry zone climatic conditions. Ampara District has granted 20 percentages in the total rice production (Ampara District Secretariat, 2016). Alayadivembu divisional secretariat (DS) division is a predominantly paddy cultivating area among the 20 DS divisions of Ampara district. Farmers in this area experience different types of risk exposures during the cultivation, namely insect pests, diseases, weeds, etc. To manage these problems, farmers mainly depend on chemical pesticides. They practice more number of applications and use high dosage of pesticides. Recently public concern related to health risks associated with pesticide residues remain in food products has been increased, substantially. Hence, it is essential to find out the current pesticide usage practices of farmers in that area. It is important to carry out awareness programmes to minimize pesticides residues in 
paddy. Therefore, a study was undertaken to assess the kind of risk exposures in paddy cultivation in this area, study the pesticide usage in paddy cultivation and evaluate the coping mechanisms used for pest management.

\section{Materials and Methods}

The study area was Alayadivembu DS division of Ampara district. It was purposively selected because the area is very popular for paddy cultivation and it accounts for intense use of pesticides. Stratified random sampling technique was used to select 100 farmers from the DS division. Data collection was done from November to December 2016 in order to collect data of Yala 2016 paddy cropping season. Primary data were gathered using pretested and structured questionnaires. Data analysis was performed using descriptive statistics, correlation analysis and ordered probit regression analysis.
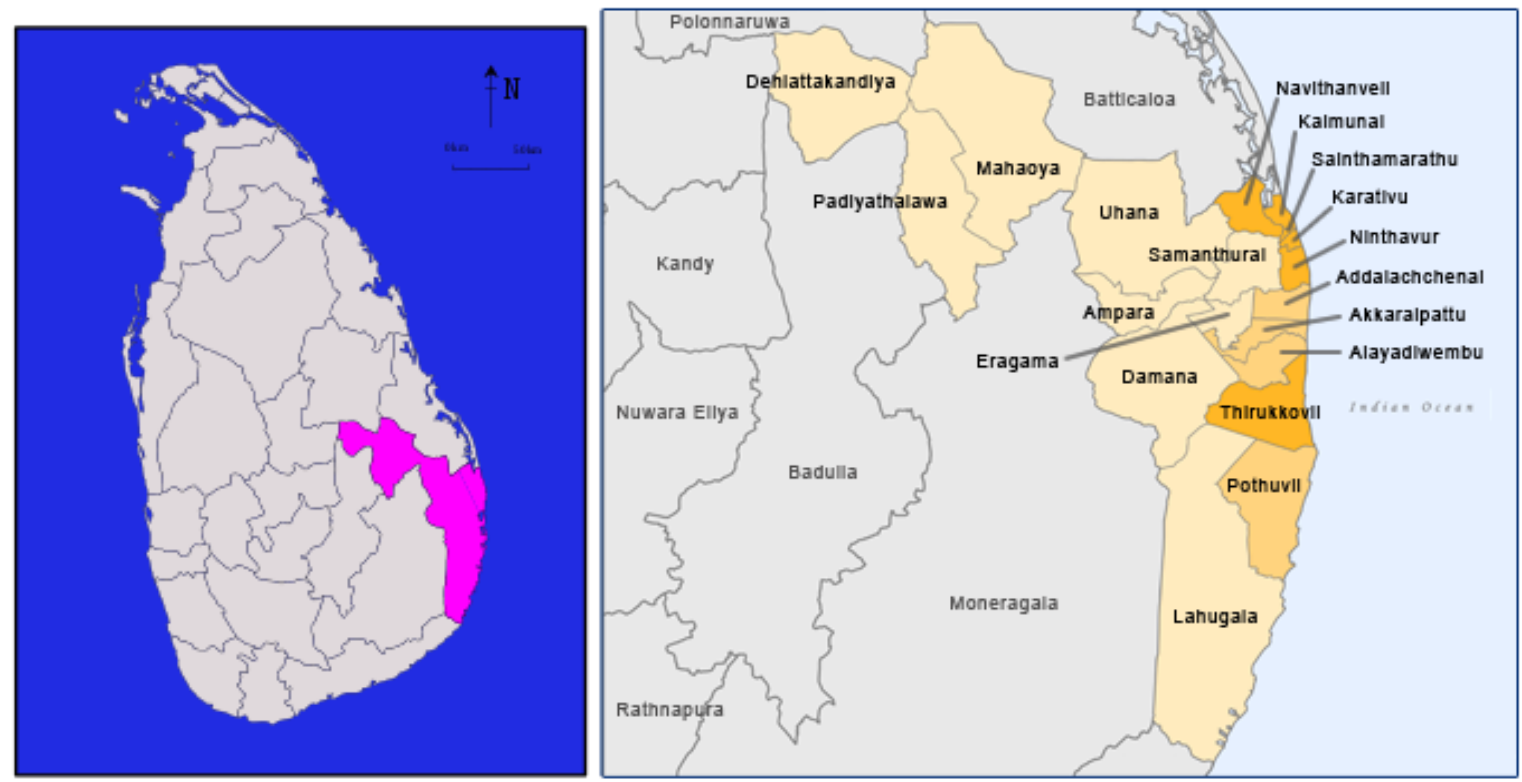

Figure 1. Study area - Alayadivembu divisional secretariat, Ampara district

\section{Results and Discussion}

\section{Descriptive Statistics}

The socio-economic characteristics of the sample studied are given in Table 1 and 2. Mean age of the farmers was 44.28 years. The average family size was 4.68 . Most of the above respondents' income was found to be a composite of various sources. Most of the respondents' main occupation was paddy farming. Monthly income of the farmers was good with the average of Rs.37,580. The average extent of cultivation was 5.35 acres where only $18 \%$ of respondents' cultivated land size was greater than 10 acres. The education level of the farmers was found to be average where the majority (38\%) studied up to Grade 5. Most of farmers (80\%) had more than 5 years of farming experience where as only $2 \%$ of the respondents were of less than one year of experience.

Table 1. Selected socio-economic characteristics of the sample

\begin{tabular}{|l|l|l|}
\hline Variables & Mean & Standard Deviation \\
\hline Age (Yrs) & 44.28 & 11.72 \\
\hline Family Size (No.) & 4.68 & 1.33 \\
\hline
\end{tabular}




\begin{tabular}{|l|l|l|}
\hline Monthly Income (Rs.) & 37580 & 15594.47 \\
\hline Land (ac) & 5.35 & 1.33 \\
\hline
\end{tabular}

Table 2. Percentage of the selected categorical variables

\begin{tabular}{|l|l|c|}
\hline Variables & Category & Percentage \\
\hline Farming Experience (Yrs) & $<1$ Year & 2 \\
\hline & $1-2$ Years & 12 \\
\hline & $2-5$ Years & 80 \\
\hline & $>5$ Years & 14 \\
\hline Education Level & Uneducated & 38 \\
\hline & Upto Year 5 & 22 \\
\hline & Year 6 upto O/L & 16 \\
\hline & A/L & 10 \\
\hline
\end{tabular}

\section{Different types of cultivated varieties}

Many varieties of paddy were cultivated in the study area. Among them, varieties BG 94-1 and AT 362 were cultivated by $42 \%$ and $34 \%$ of farmers respectively, in large extents.

\section{Kinds of biotic risks experienced in paddy cultivation}

It was found that weeds are the major constraint (96\%) followed by the insect damage (88\%) whereas fungal attacks were minimal (28\%) in the study area. About $72 \%$ of the respondents reported the prevalence of Jungle Rice weed. Among the insect pests, brown planthopper was the most serious insect (70\%) causing yield loss. Brown planthopper is one of the most damaging rice pests in Sri Lanka (Madurangi et al., 2010).

\section{Coping mechanisms to manage the risks}

All the respondents (100\%) in the study area depend on chemical pesticides to mitigate the biotic risks of paddy cultivation (Figure 2). Farmers assume that the only solution to pest problems is to spray more frequently and using different types of pesticides (Dunham, 1995). Several authors (Kumarapeli, 2006; Niyarapola et al., 2008) reported that herbicides were the widely used pesticides in paddy cultivation. About $84 \%, 80 \%$ and $10 \%$ of farmers applied pretilachlor weedicide, thiamethoxam insecticide and sulphur dust fungicide, respectively. 


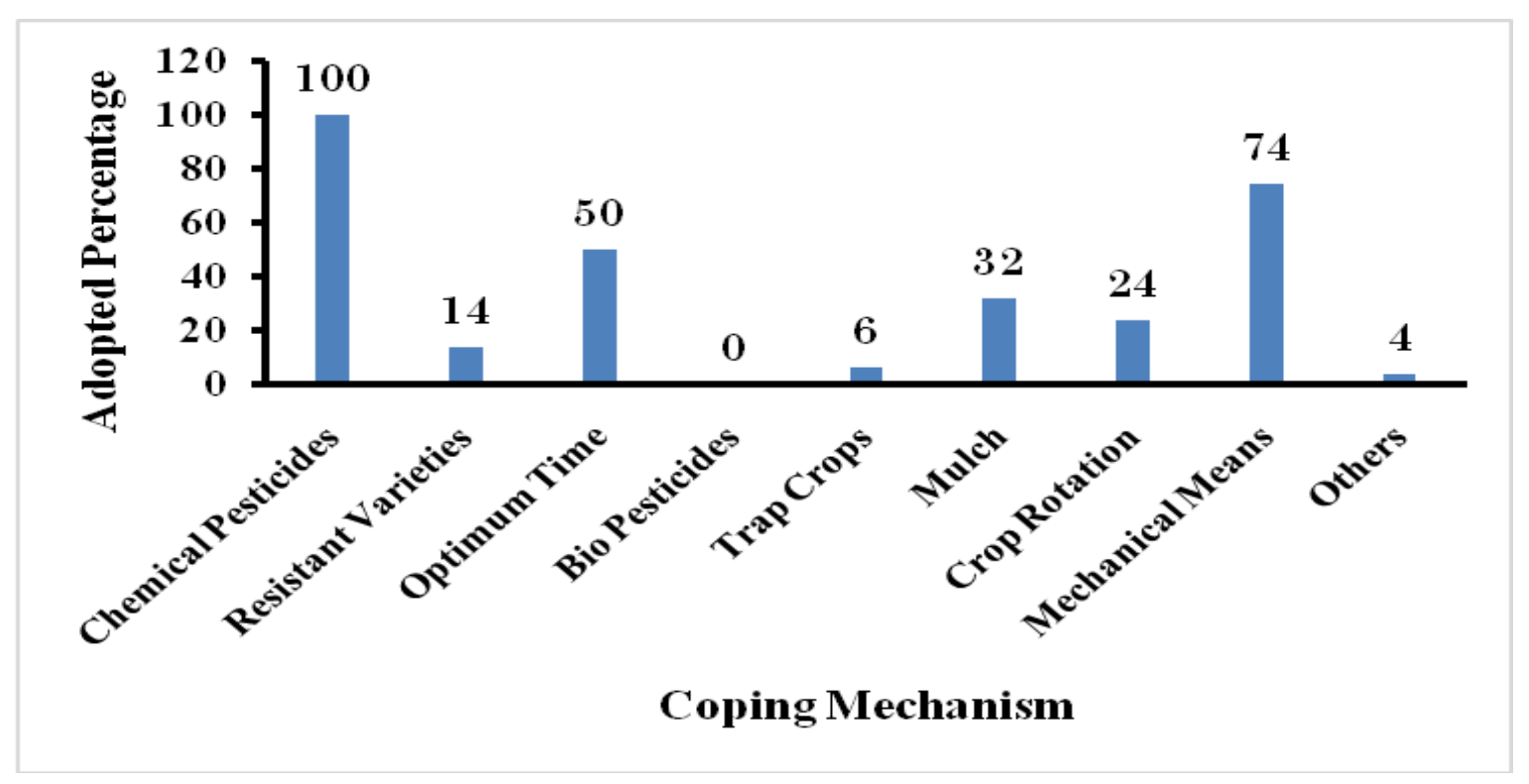

Figure 2. Percentage of farmers practicing different coping mechanisms

\section{Different precautionary measures used in handling pesticides}

It was observed that $96 \%$ of farmers were well aware that pesticides should be kept away from children. About $68 \%$ of farmers disposed the pesticides containers safely.

\section{Expected trend of pesticides usage in the area}

Even though the farmers are aware of the ill effects of chemical pesticides they are likely to increase the pesticide usage to achieve maximum yield and money return.

\section{Knowledge on integrated pest management}

It is important to note that $74 \%$ of farmers had knowledge on integrated pest management (IPM) in paddy cultivation. About $62 \%$ of respondents received information on IPM from the Department of Agriculture, Sri Lanka. The second most (56\%) source of the farmers for the IPM information was their neighboring farmers.

\section{Access to extension service}

It was observed that only $32 \%$ of the farmers had the access to extension service whereas majority of the farmers $(68 \%)$ could not receive extension services.

\section{Correlation Analysis}

Correlation analysis shows a significant positive correlation $\left(\mathrm{R}^{2}=0.72 ; \mathrm{P}=0.036\right)$ of farmers' income with their extent of paddy cultivation. Furthermore, farmers knowledge on IPM had a significantly higher positive correlation $\left(\mathrm{R}^{2}=0.81 ; \mathrm{P}=0.014\right)$ with their education level. 


\section{Ordered Probit Regression Analysis}

The results of the probit analysis of the 100 observations are presented in Table 3 . The goodness of fit of the model shows reasonably high pseudo $\mathrm{R}^{2}$ of 0.56 and significant at $1 \%$ level, which suggests that $56 \%$ of the variability in correct identification of risk in paddy cultivation can be explained by the eight selected socioeconomic variables in the ordered probit regression model. The ordered probit model focused on factors that influence the farmers' ability to identify the risk in their cultivation. Farming experience, educational level and access to extension service were positive and significantly contributed to farmers' ability to identify the risk in their cultivation. Farming experience is a key factor for wise decisions of farmers in the field (Nagenthirarajah and Thiruchelvam, 2008).

Ordered Probit Model:

$$
Y=\beta_{0}+\beta_{1} X 1+\beta_{2} X 2+\beta_{3} X 3+\beta_{4} X 4+\beta_{5} X 5+\beta_{6} X 6+\beta_{7} X 7+\varepsilon
$$

$\mathrm{Y}=$ Correct identification of risk

$$
\begin{aligned}
& Y=1, \text { if can identify correctly } \\
& Y=0, \text { if cannot identify correctly }
\end{aligned}
$$

$$
\begin{aligned}
& \mathrm{X} 1=\text { Age } \\
& \mathrm{X} 2=\text { Family Size } \\
& \mathrm{X} 3=\text { Farming Experience } \\
& \mathrm{X} 4=\text { Educational Level } \\
& \mathrm{X} 5=\text { Income } \\
& \mathrm{X} 6=\text { Land Area } \\
& \mathrm{X} 7=\text { Access to extension service }(\mathrm{Yes}=1, \text { No }=0)
\end{aligned}
$$

Table 3. Factors influencing farmers' ability to identify risk correctly

$$
\begin{array}{ll}
\text { Number of observations }=100 & \operatorname{LR~chi}^{2}(7)=51.94 \\
\text { Prob }>\text { chi }^{2}=0.0000 & \text { Pseudo } \mathrm{R}^{2}=0.5581
\end{array}
$$

\begin{tabular}{|l|l|l|l|}
\hline Variables & Coefficient & Std. Err. & P Value \\
\hline Age & -0.0739 & 0.2452 & 0.731 \\
\hline Family Size & $-1.25808^{*}$ & 0.1569 & 0.088 \\
\hline Farming Experience & $0.0335^{* *}$ & 0.1239 & 0.029 \\
\hline Educational Level & $0.1889 * * *$ & 0.0643 & 0.000 \\
\hline Income & $3.43 \mathrm{e}-06$ & $2.61 \mathrm{e}-06$ & 0.413 \\
\hline Land Area & -0.4792 & 0.1839 & 0.841 \\
\hline $\begin{array}{l}\text { Access to Extension } \\
\text { Service }\end{array}$ & $2.5159 * * *$ & 0.8231 & 0.001 \\
\hline
\end{tabular}

(**Significant at 0.05 level, *** Significant at 0.01 level) 


\section{Conclusions}

Weed problem was the chief risk experienced by the farmers. All the farmers are dependent on chemical pesticides. Extent of paddy cultivation and farmers' educational level had significant influence on farmers' income and their knowledge on IPM respectively. Educational level, farming experience and access to extension service had a positive and significant relationship on correct identification of risk. It is recommended to increase the effective extension services, motivate farmers to better use of pesticides through generating awareness about ill effects of chemical pesticides and provide farmer training campaign on alternative aspects of pest control strategies such as IPM.

\section{References}

Central Bank of Sri Lanka. (2016). Annual Report 2016. Central Bank of Sri Lanka. Chapter 1, p. 4.

Amapara District Secretariat. (2016). Annual Performance Report and Accounts 2016. District Secretariat, Ampara. p. 26.

Dunham, D. (1995). Contract Farming and Export Horticulture: Can Agribusiness Revitalise the Peasant Sector in Sri Lanka? IPS Agricultural Policy Series No. 3. Institute of Policy Studies. Colombo. p 34.

Kumarapeli, C.P. (2006). Farmers Preference for Agro-chemicals Used for Food Crops. Unpublished M.Sc. Thesis. University of Sri Jayewardenepura, Sri Lanka. p. 29.

Madurangi, S.A.P., Ratnasekera, D., Hemachandra, P.V. and Senanayake, S.G.J.N. (2010). Evaluation of brown planthopper Nilaparvata lugens (Stal) resistance in Oryza nivara wild rice accessions found in Sri Lanka. Proceedings of the $15^{\text {th }}$ International Forestry and Environment Symposium, Department of Forestry and Environmental Science, University of Sri Jayewardenepura, Sri Lanka. 26-27 November 2010. pp. 172-175

Nagenthirarajah, S. and Thiruchelvam, S. (2008). Knowledge of Farmers about Pest Management Practices in Pambaimadu, Vavuniya District: An Ordered Probit Model Approach. Sabaragamuwa University Journal. 8(1): 79-89.

Niyarapola, H.M.N.I., Wickramasinghe, Y.M. and Herath, R.M. (2008). Pesticides Buying Behavior of Paddy Farmers' in the Nuwaragampalathe-East Divisional Secretariat Division in Anuradhapura District. Proceedings of Undergraduate Research Symposium - 2008, Faculty of Agriculture, Rajarata University of Sri Lanka. 2: 1617. 